\title{
Knowledge, Attitude, and Practice of Agrochemicals Use among Farmers in Kathmandu, Nepal
}

\author{
Sharmila Ranabhat ${ }^{1}$, Suman Baskota ${ }^{2}$, Bishnu Bajagain ${ }^{3}$ \\ ${ }^{1}$ Ex-Assistant Professor, Department of Rural Development, Tri Chandra Multiple Campus, Tribhuvan \\ University, Kathmandu, Nepal \\ ${ }^{2}$ Ex-Assistant Professor, Central Department of Statistics, Tribhuvan University, Kathmandu, Nepal \\ ${ }^{3}$ Research Associate, Department of Community Health Sciences, Cumming School of Medicine, University of \\ Calgary, Alberta, Canada \\ Corresponding Author: Sharmila Ranabhat
}

\begin{abstract}
Background and purpose: High agricultural inputs such as chemical fertilizer and pesticides are unlikely to be sustainable for long unless the inputs are properly used in terms of both their quality and quantity. Because of limited knowledge and skills about the use of chemical fertilizers and pesticides, farmers are haphazardly using agrochemical, which not only disturbs the soil ecosystem, affecting the nutrient recycling process and decreases productivity, but also affects long-term human health. It has a potential connection to cancer, thyroid, and reproductive health in both humans and livestock. Heavy use of chemical herbicides, pesticides, and intensification of agricultural production during the past few decades has led to several harmful effects in surrounding areas of Kathmandu valley. In this context, this study was conducted to assess the farmer's knowledge towards the use of agrochemicals, to explore the attitude, and practices methods of chemical fertilizer and pesticides in Sankhu and Machhegaun VDCs, Kathmandu, Nepal. As well, this study explored the famers' selfreported problems associated with the use of agrochemicals.

Materials and Methods: In this study, two sampling methods: purposive and snowball sampling was used to select 50 farmers from two villages in Kathmandu, Nepal. The data was obtained by interview and focus group discussion through structured questionnaires and checklists, which were analyzed with descriptive statistical tools.

Results and conclusion: Almost half of the farmers (40\%) access information about agrochemicals use from friends, elders, relatives, and other farmers followed by agrochemicals retailers and agriculture cooperatives (22\%). All the farmers in the study area were aware of the hazards involved in agrochemicals and safety precautions. However, the majority of them (68\%) ignored safety precautions while applying agrochemicals. Research revealed that females are more likely to use safety measures than males among those who used safety measures and the higher educational status of respondents plays a vital role in applying safety measures. The most common PPE used by slightly more than a quarter of farmers were rubber gloves, safety shoes, masks, hats, long-sleeved clothes, goggles, and respirators. Furthermore, only $26 \%$ of farmers have ever received some kind of training to use agrochemicals. All the farmers washed their hands with soap while only $18 \%$ of them took bath immediately after applying agrochemicals. Slightly more than half $(52 \%)$ of the farmers stored agrochemicals in an unlocked cabinet inside the house and only $14 \%$ locked in the safe place outside. Almost half of the farmers (48\%) threw away empty agrochemicals in the open space (48\%) and 36\% of them were reused for storage or other household purposes. Only $8 \%$ used the safe disposal procedure i.e., burn or bury. The common time interval (38\%) between agrochemicals application and crop harvesting was between one to two weeks followed by two to three weeks (30\%). More than half of the farmers (54\%) reported that pest and insect activity increased after agrochemicals application. Similarly, some farmers also reported experiencing adverse impacts on their animals (14\%) and the surrounding environment. The study revealed that the majority of the farmers 39 (78\%) had ill-health
\end{abstract}


symptoms after agrochemicals application. The most common symptoms experienced by them were eye irritation, headache, cough, skin rashes or allergy, vomiting, dizziness, and abdominal pain. Some farmers also reported chronic illnesses such as asthma and bronchitis.

Inadequate knowledge and inappropriate practice have resulted in harmful consequences to the farmers' health and the surrounding environment. Based on the results of the study, training for farmers is strongly recommended to improve knowledge on agrochemical use, risk associated with agrochemical, safety precaution, safe storage and disposal and short and long-term health impact. Furthermore, to manage inappropriate disposal practices of the farmers, the local government should provide a common agrochemicals waste disposal site where there is no threat to public health and the environment.

Key words: agrochemicals, pesticides, chemical fertilizer, human health, PPE, environment

\section{INTRODUCTION}

Agriculture is at the core of the livelihoods of most rural households in Nepal, which accounts for 36 percent of the country's gross domestic product (GDP) and offers employment opportunities to 66 percent of the total population. ${ }^{(1)}$ Although measures to enhance the rural farm economy are reflected in various national policies and plans, the performance of this sector has been inadequate to meet the increasing food demand, alleviate poverty, uplift the living standard, and expand smallholder farm productiveness in the country.

The application of chemical fertilizer and pesticides became a crucial part to increase agricultural productivity and change the agricultural existing scenario in Nepal. The 20-year Agriculture Perspective Plan (APP), implemented in 1997, has also recognized agrochemicals as an engine of agriculture growth. ${ }^{(2)}$ National Agriculture Policy, 2004, an umbrella policy in the agricultural sector to guide all sectoral policies, has also recommended the application of agrochemicals in high production potential areas that helped to increase demand for and use of chemical fertilizer in the country. (3) With the government's emphasis and growing popularity of agricultural modernization and intensification, agrochemicals consumption in Nepal has been increasing over the years. (2) There has been a growing tendency each year (shown in the table below) in the application of chemical fertilizer in the country, from 2,58,779 metric tonnes in
2016 to $3,48,734.62$ metric tonnes in 2018 . (4)

Table 1. Mostly sold chemical fertilizers and pesticides in Nepal (Quantity in metric tonnes)

\begin{tabular}{|l|l|l|l|}
\hline Names & $\mathbf{2 0 1 6}$ & $\mathbf{2 0 1 7}$ & $\mathbf{2 0 1 8}$ \\
\hline Chemical fertilizer & $2,58,779.00$ & $3,28,216.9$ & $3,48,734.62$ \\
\hline Urea & $1,64,641.50$ & $2,05,424.85$ & $2,35,304.35$ \\
\hline $\begin{array}{l}\text { Diammonium } \\
\text { Phosphate (DAP) }\end{array}$ & $87,572.80$ & $1,14,801.55$ & $1,05,619.17$ \\
\hline Potash & $6,564.80$ & $7,990.5$ & $7,811.10$ \\
\hline \multicolumn{3}{|c|}{ Source: Krishi Diary, 2019} \\
\hline
\end{tabular}

The proper use of pesticides, chemical fertilizer and other agrochemicals enhance the expected yields. However, improper practice contributes to an extensive range of ecological problems. Similarly, they also bio-accumulate in the food chain and can be traced in plant and animal tissues causing serious health hazards. ${ }^{(5)}$ The application of pesticides is increasing in Nepal not knowing the proper use and their effect on the environment, ecosystem, and health of living beings. ${ }^{(6)}$ The broad spectrum of regular misuse of pesticides in Nepal has been causing pests to adapt and emerge as resistant to the pesticides, hence, required at higher doses to achieve the identical level of control, though often these are not as effective. ${ }^{(7)}$

The agrochemicals are associated with acute health problems for workers who manage the chemicals, such as abdominal pain, dizziness, headaches, nausea, vomiting, as well as skin and eye problems. ${ }^{(8)}$ Excessive air- and water-borne nitrogen from fertilizers may also cause respiratory ailments, cardiac disease, and several cancers, as well as can "inhibit crop growth, increase allergenic pollen production, and 
potentially affect the dynamics of several vector-borne diseases, including West Nile virus, malaria, and cholera." (9) The World Health Organization and the UN Environmental Programme estimate that each year, three million workers in agriculture in the developing world experience severe poisoning from pesticides, about 18,000 of them could not survive. ${ }^{(10)}$

Despite upward tendencies in agrochemicals use in agriculture production in Nepal over the past few decades, it is extensively viewed that farmers are not safely using agrochemicals due to their confined knowledge. A study conducted ${ }^{(11)}$ in Chitwan, Nepal found inadequate knowledge of farmers on various aspects of a pesticide that includes the use, types, characteristics, selection, and overall handling. Other studies carried out in Rupandehi, Palpa, Chitwan and Kathmandu, Nepal also indicate a similar result that suggests that the farmers had limited awareness about safe pesticide management, safe application procedure, environmental, and health hazard. (12,13,6,14). Another research (15) also identified farmers in Lumle, Nepal using agrochemicals in a high quantity, assuming that would increase production. In a study by Sharma et al., revealed that $54 \%$ of farmers did not adopt any safe pesticide disposal mechanism in their study. ${ }^{(13)}$

The population growth in Kathmandu valley, which consists of Kathmandu, Lalitpur, and Bhaktapur, has increased notably in last three decades estimated between 2.2 and 2.5 million people living in the Kathmandu valley. ${ }^{(16)}$ With the increase in population size leading to the high demand for vegetables in the valley, there is an enormous increase of vegetable growers in the surrounding areas of Kathmandu valley. ${ }^{(17)}$ The Increment in population and high vegetable demand also resulted in many farmers around urban and peri-urban areas moving towards the commercial production of vegetables. ${ }^{(18)}$ As a result, a tremendous increment of agrochemical inputs such as chemical fertilizers and other plant nutrients, crop seeds, and pesticides in vegetable production can be observed. ${ }^{(11)}$

Excessive use of agrochemicals in agricultural production in the past few decades has led to many damaging consequences in peri-urban areas of Kathmandu Valley. Farmer's knowledge on agrochemicals uses and potential risk is crucial in sustainable livelihood and in preventing agrochemicals exposure to humans, plants, and animals. Thus, this study aims to assess the farmer's knowledge, attitude, and practices towards the use and practice of such agrochemicals in Sankhu and Machhegaun Village Development Committee, Kathmandu. The specific objective of this study was to determine farmers' general knowledge of agrochemicals use; to assess farmers' attitude towards the use of agrochemicals; to explore the farmers' practice method of chemical fertilizer and pesticides; to ascertain the problems associated with the usage of chemical fertilizers and pesticides by farmers. To the best of our knowledge, these issues have not been studied in this area. The findings of the study will be significant to the policymakers to identify the gaps, develop a training program, and advocate on it to address the challenges of farmers.

\section{MATERIALS AND METHODS}

The study was carried out in two villages, Sankhu and Machhegaun, of Kathmandu District, Nepal. Sankhu is approximately $17 \mathrm{~km}$ away from the capital city, Kathmandu. The geographic coordinates of Sankhu are $27^{\circ} 43^{\prime} 0^{\prime}$ ' North, $85^{\circ} 27^{\prime} 0^{\prime \prime}$ East. Machhegaun is about $8 \mathrm{~km}$ away from the center of Kathmandu city with geographic coordinates of $27.66^{\circ} \mathrm{N}$ $85.25^{\circ} \mathrm{E}$. According to CBS, 2011 , the total population of the Sankhu, Bajrayogini and Machhegaun VDC is 4,333 (928 households) and 3,849 (872 households) respectively. 
Sharmila Ranabhat et.al. Knowledge, attitude, and practice of agrochemicals use among farmers in Kathmandu, Nepal.

The total 50 households (30 households from Sankhu and 20 households from Machhegaun) were selected using a combination of two sampling methods: purposive and snowball sampling. The participants were recruited based on their predominant occupation as agriculture, particularly vegetable farming.

This study was a qualitative approach and based on descriptive and explanatory research design. The data was collected via semi-structured in-person interviews and focus group discussion to describe the attitude, knowledge, and practice of farmers towards chemical fertilizer and pesticides; and explore problems and constraints they have been facing whilst applying such chemical inputs. All the interviews and field observations were well maintained on the note. The interviews and observation ranged from 4560 minutes.

The collected data was sorted, tabulated, and processed manually using simple statistical procedures. The data recorded during the in-person interviews and observation was first coded, categorized, processed, and analyzed using Microsoft Word and Excel. The statistical measures used were frequency, chi-square, percentage, and average.

\section{RESULTS}

\subsection{Sociodemographic Characteristics of the study population}

Table 2. Demographic characteristics of study population

\begin{tabular}{|l|l|l|}
\hline $\begin{array}{l}\text { Sociodemographic } \\
\text { variables }\end{array}$ & $\begin{array}{l}\text { Study population } \\
(\mathbf{N})\end{array}$ & $\begin{array}{l}\text { Percentage } \\
(\%)\end{array}$ \\
\hline Age (in years) & & \\
\hline 20-30 Years & 10 & 20 \\
\hline 31-40 Years & 28 & 56 \\
\hline 41-50 Years & 12 & 24 \\
\hline Gender & & \\
\hline Female & 28 & 56 \\
\hline Male & 22 & 44 \\
\hline Level of Education & & \\
\hline Primary level & 13 & 26 \\
\hline Secondary level & 24 & 48 \\
\hline Higher secondary level & 13 & 26 \\
\hline
\end{tabular}

Out of the total respondents in two VDCs, Sanknu and Machhegaun, slightly more than half $(56 \%)$ of the respondents were female. The majority of the respondents were between the age of 31-40 years, followed by between the ages of 4150 years $(24 \%)$ and between the ages of 20 30 years $(20 \%)$ and, slightly less than half $(48 \%)$ reported having secondary level education followed by $(26 \%)$ higher secondary level (Table 2).

\subsection{Knowledge about agrochemicals (fertilizer and pesticides)}

The study revealed that all of farmers $(100 \%)$ were aware of agrochemicals and slightly more than half of them $(54 \%)$ were applying it for one to five years followed by five to 10 years $(24 \%)$ as mentioned in table 2 . The majority of them $(58 \%)$ bought agrochemicals from both private retailers and agriculture cooperatives. A significant proportion $(76 \%)$ of farmers reported that agrochemicals are not affordable to them. The most used agrochemicals in the research area were urea, DAP, potash, and various pesticides including animal dung and other organic inputs, and a maximum number of farmers (92\%) applied all those agricultural inputs.

Table 3. Knowledge about agrochemicals (fertilizer and pesticides)

\begin{tabular}{|c|c|c|}
\hline Variable & Frequency $(\mathbf{N})$ & $\%$ \\
\hline \multicolumn{3}{|c|}{ Knowledge about agrochemicals (fertilizer and pesticides) } \\
\hline Yes & 50 & 100 \\
\hline No & 0 & \\
\hline \multicolumn{3}{|l|}{ Years of applying agrochemicals in farm } \\
\hline$<1$ years & 4 & 8 \\
\hline 1-5 Years & 27 & 54 \\
\hline 6-10 Years & 12 & 24 \\
\hline$\geq 10$ years & 7 & 14 \\
\hline \multicolumn{3}{|l|}{ Buying sources of agrochemicals } \\
\hline Private retailers & 8 & 16 \\
\hline $\begin{array}{lll}\text { Agriculture cooperatives } & \text { including } \\
\text { Sajha } & & \end{array}$ & 13 & 26 \\
\hline Both & 29 & 58 \\
\hline \multicolumn{3}{|l|}{ Cost affordability of agrochemicals } \\
\hline Yes & 12 & 24 \\
\hline No & 38 & 76 \\
\hline \multicolumn{3}{|c|}{$\begin{array}{l}\text { Type of agrochemicals or organic manure applying in the } \\
\text { field? }\end{array}$} \\
\hline Urea & 41 & 82 \\
\hline DAP & 34 & 68 \\
\hline Potash & 47 & 94 \\
\hline Animal dung and other organic inputs & 37 & 74 \\
\hline Various pesticides & 44 & 88 \\
\hline Above all & 46 & 92 \\
\hline
\end{tabular}


Sharmila Ranabhat et.al. Knowledge, attitude, and practice of agrochemicals use among farmers in Kathmandu, Nepal.

\subsection{Source of information about agrochemicals use}

Most of the farmers $(40 \%)$ received information about agrochemicals use from friends, elders, relatives, and other farmers whereas slightly less than a quarter $(22 \%)$ of them received information from agrochemicals retailers and agriculture cooperatives. Few of them (14\%) applied agrochemicals following the information on radio, television, newspapers, and pamphlets.

The field observation highlights that the majority of farmers were growing potatoes, ginger, cauliflower, cabbage, tomato, radish, onion, garlic, chilli, beans, and other leafy vegetables. Many farmers use groundwater for household purposes, watering vegetables including drinking purposes which poses their health at risk.

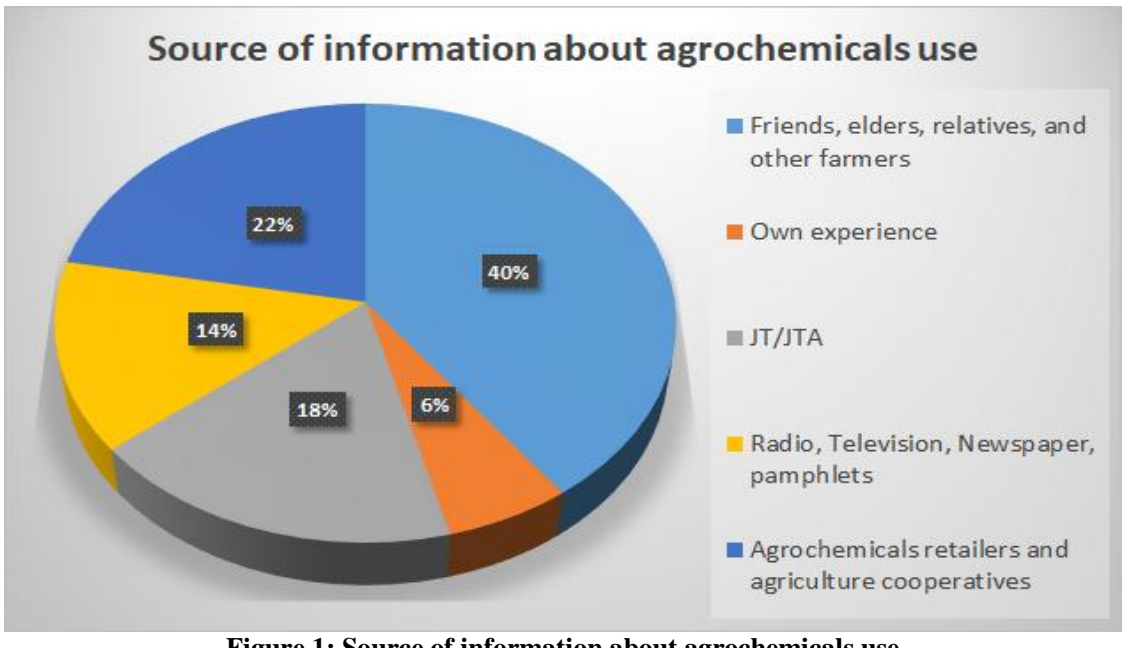

Figure 1: Source of information about agrochemicals use

\subsection{Farmers' attitude towards the use of agrochemicals}

A great majority of farmers $(98 \%)$ as shown in figure 1 below agreed that agrochemicals were required for better crops and to increase production (70\%). However, they were also concerned about the increment of production cost $(84 \%)$ and weed growth (84\%). A slightly less than a half $(44 \%)$ respondents agreed with a statement that chemical fertilizer and pesticides reduce the quality of crops and $34 \%$ believe it is not necessarily good for farming.

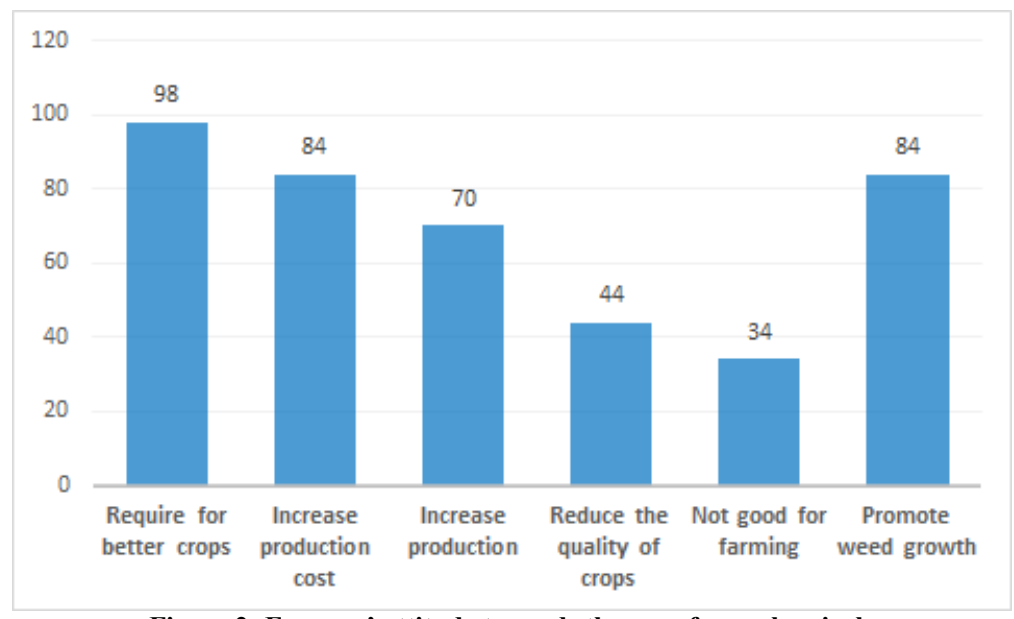

Figure 2: Farmers' attitude towards the use of agrochemicals

3.5. Knowledge and practices of agrochemicals use among Farmers

The study indicated that only $26 \%$ of farmers have ever received some kind of training to use agrochemicals. All the farmers $(100 \%)$ in the study area were aware of the hazards involved in agrochemicals and safety precautions. 
Sharmila Ranabhat et.al. Knowledge, attitude, and practice of agrochemicals use among farmers in Kathmandu, Nepal.

However, only $32 \%$ of them applied safety measures while applying it. Among those 16 $(32 \%)$ who applied safety measures, only 4 $(25 \%)$ of them wore all required personal protective equipment (PPE). Rubber gloves $(n=14)$, safety shoes $(n=7)$, mask $(n=15)$, hat $(n=4)$, long-sleeved clothes $(n=16)$, a pair of goggles $(n=11)$ and respirator $(n=5)$ were most common PPE used by farmers. All the farmers $(100 \%)$ reported that they washed their hands with soap after applying agrochemicals whereas only $18 \%$ of them took shower immediately after applying agrochemicals.

The majority of farmers $(38 \%)$ applied pesticides one to two weeks before harvesting the vegetables followed by two to three weeks and four weeks and above. Seventy percent of farmers used both hand and modern spraying equipment to apply pesticides.

Table 4. Knowledge and practices of agrochemicals use among Farmers

\begin{tabular}{|c|c|c|c|}
\hline Variable & Response & Frequency (N) & $\%$ \\
\hline \multirow{2}{*}{ Awareness of hazards involved in agrochemicals } & Yes & 50 & 100 \\
\hline & $\mathrm{No}$ & 0 & 0 \\
\hline \multirow[t]{2}{*}{ Received any training to use agrochemicals } & Yes & 13 & 26 \\
\hline & No & 37 & 74 \\
\hline \multirow[t]{2}{*}{ Knowledge about the safety precaution while applying agrochemicals } & Yes & 50 & 100 \\
\hline & No & 0 & 0 \\
\hline \multirow[t]{2}{*}{ Taken required safety measures while applying agrochemicals } & Yes & 16 & 32 \\
\hline & No & 34 & 68 \\
\hline \multirow[t]{8}{*}{ If yes, list of personal protective equipment used while applying agrochemicals? } & Rubber gloves & 14 & 87.5 \\
\hline & Safety shoes & 7 & 43.75 \\
\hline & Mask & 15 & 93.75 \\
\hline & Hat & 4 & 25 \\
\hline & Long sleeved cloths & 16 & 100 \\
\hline & Googles & 11 & 68.75 \\
\hline & Respirator & 5 & 31.25 \\
\hline & All of the above & 4 & 25 \\
\hline \multirow[t]{4}{*}{ Time interval practiced between pesticide application and crop harvesting } & Less than 1 week & 7 & 14 \\
\hline & $1-2$ weeks & 19 & 38 \\
\hline & $2-3$ weeks & 15 & 30 \\
\hline & 4 weeks and above & 9 & 18 \\
\hline \multirow[t]{3}{*}{ Types of equipment used in agrochemical application } & Modern spraying equipment & 5 & 10 \\
\hline & Hand & 10 & 20 \\
\hline & Both & 35 & 70 \\
\hline \multirow[t]{2}{*}{ Wash hand with soap after applying agrochemicals } & Yes & 50 & 100 \\
\hline & No & 0 & 0 \\
\hline \multirow[t]{3}{*}{ Take shower immediately after applying agrochemicals } & Yes & 9 & 18 \\
\hline & No & 29 & 58 \\
\hline & Sometimes & 12 & 24 \\
\hline
\end{tabular}

Table 5. Relationship of applying safety measures with gender and education and gender and training Relationship of applied safety measures and gender

\begin{tabular}{|c|c|c|c|c|c|c|}
\hline \multicolumn{7}{|c|}{ Relationship of applied safety measures and gender } \\
\hline & \multirow[t]{2}{*}{ Response } & \multicolumn{2}{|l|}{ Gender } & & Calculated Chi- & Result \\
\hline & & Male & Female & & \multirow[t]{3}{*}{$7.76^{*}$} & \multirow{3}{*}{$\begin{array}{l}\text { Significant at } 0.05 \\
\text { level and } 1 \text { d.f. }\end{array}$} \\
\hline \multirow{2}{*}{$\begin{array}{l}\text { Taken required safety measures } \\
\text { while applying agrochemicals }\end{array}$} & Yes & 2 & 14 & & & \\
\hline & No & 20 & 14 & & & \\
\hline \multicolumn{7}{|c|}{ Relationship of level of education and applying safety measures } \\
\hline & Response & \multicolumn{3}{|c|}{ Education } & & \\
\hline & & Primary & Secondary & Higher Secondary & \multirow[t]{3}{*}{$11.34 *$} & \multirow{3}{*}{$\begin{array}{l}\text { Significant at } 0.05 \\
\text { level and } 2 \text { d.f. }\end{array}$} \\
\hline \multirow{2}{*}{$\begin{array}{l}\text { Taken required safety measures } \\
\text { while applying agrochemicals }\end{array}$} & Yes & 3 & 4 & 9 & & \\
\hline & No & 10 & 20 & 4 & & \\
\hline \multicolumn{7}{|c|}{ Relationship of training received and gender } \\
\hline \multirow{4}{*}{$\begin{array}{l}\text { Received any training to use } \\
\text { agrochemicals }\end{array}$} & & \multicolumn{2}{|l|}{ Gender } & & \multirow[t]{4}{*}{$1.93 *$} & \multirow{4}{*}{$\begin{array}{l}\text { *Insignificant at } 0.05 \\
\text { level and } 1 \text { d.f. }\end{array}$} \\
\hline & Response & Male & Female & & & \\
\hline & Yes & 8 & 5 & & & \\
\hline & No & 14 & 23 & & & \\
\hline
\end{tabular}

Using the chi-square test at $5 \%$ level of significance, it can be concluded that the relationship between taking safety measures depends on gender $\left(\chi_{0.05,1}^{2}=7.76\right)$ and females are more likely to practice safety measures than males. Similarly, there is a significant $\left(\chi_{0.05,2}^{2}=11.34\right)$ relationship between education and taking safety 
Sharmila Ranabhat et.al. Knowledge, attitude, and practice of agrochemicals use among farmers in Kathmandu, Nepal.

measures, as respondents with higher education are more likely to use safety measures than respondents with lower education. On the other hand, there is no significant $\left(\chi_{0.05,1}^{2}=1.93\right)$ relationship between gender and receiving training (Table 5).

\subsection{Practices of Agrochemical storage and Disposal}

Table 6. Practices of Agrochemical storage and Disposal

\begin{tabular}{|c|c|c|c|}
\hline Variable & Response & $\begin{array}{l}\text { Frequency } \\
\text { (N) }\end{array}$ & $\%$ \\
\hline \multirow[t]{4}{*}{$\begin{array}{l}\text { Store of } \\
\text { agrochemicals }\end{array}$} & $\begin{array}{l}\text { Unlocked cabinet inside } \\
\text { the house }\end{array}$ & 26 & 52 \\
\hline & $\begin{array}{l}\text { Locked cabinet inside the } \\
\text { house }\end{array}$ & 13 & 26 \\
\hline & $\begin{array}{l}\text { Locked in the safe place } \\
\text { outside }\end{array}$ & 7 & 14 \\
\hline & $\begin{array}{l}\text { Unlocked open } \\
\text { outside }\end{array}$ & 4 & 8 \\
\hline \multirow{6}{*}{$\begin{array}{l}\text { Handling } \\
\text { practices of } \\
\text { leftover } \\
\text { agrochemicals }\end{array}$} & $\begin{array}{l}\text { Store and use for next } \\
\text { time }\end{array}$ & 29 & 58 \\
\hline & $\begin{array}{l}\text { Sell or give away to other } \\
\text { farmers }\end{array}$ & 6 & 12 \\
\hline & $\begin{array}{l}\text { Pour into open farmland } \\
\text { nearby }\end{array}$ & 3 & 6 \\
\hline & $\begin{array}{ll}\begin{array}{l}\text { Pour } \\
\text { buses/river/stream }\end{array} & \text { into } \\
\end{array}$ & 0 & 0 \\
\hline & Apply even if not required & 8 & 16 \\
\hline & Dispose on the soil & 4 & 8 \\
\hline \multirow{3}{*}{$\begin{array}{l}\text { Dispose } \\
\text { practices of } \\
\text { agrochemical } \\
\text { containers }\end{array}$} & Burn or bury & 4 & 8 \\
\hline & $\begin{array}{l}\text { Used for food storage, or } \\
\text { other household purpose }\end{array}$ & 18 & 36 \\
\hline & $\begin{array}{l}\text { Throw away in open } \\
\text { space }\end{array}$ & 24 & 48 \\
\hline
\end{tabular}

The table above shows the agrochemical storage and disposal practice. Slightly more than half $(52 \%)$ of the farmers stored agrochemicals in an unlocked cabinet inside the house and only $14 \%$ locked in the safe place outside. The leftover agrochemicals were stored for next time use by $58 \%$ of farmers whereas $16 \%$ of them just applied it to finish the agrochemicals even if it was not required. Some of the farmers disposed of it on the soil (8\%), poured it into open farmland nearby $(6 \%)$ and sold or gave it away to other farmers $(12 \%)$. Almost half of the farmers $(48 \%)$ threw away empty agrochemicals in the open space (48\%) and $36 \%$ of them were reused for storage or other household purposes. Only $8 \%$ used the safe disposal procedure i.e., burn or bury.

\subsection{Self-reported impact of agrochemicals uses among Farmers}

Table 7. Self-reported impact of agrochemicals uses among Farmers

\begin{tabular}{|c|c|c|c|}
\hline Variable & Response & $\begin{array}{l}\text { Frequency } \\
\text { (N) }\end{array}$ & $\%$ \\
\hline \multirow{2}{*}{$\begin{array}{l}\text { Any ill-health } \\
\text { symptoms after } \\
\text { applying } \\
\text { agrochemicals }\end{array}$} & Yes & 39 & 78 \\
\hline & No & 11 & 22 \\
\hline \multirow{10}{*}{$\begin{array}{l}\text { Symptoms you or } \\
\text { your family } \\
\text { members } \\
\text { experiencing after } \\
\text { applying } \\
\text { agrochemicals }\end{array}$} & Eye irritation & 21 & 53.84 \\
\hline & Headache & 14 & 35.89 \\
\hline & Fever & 2 & 5.12 \\
\hline & Cough & 7 & 17.94 \\
\hline & Vomiting & 5 & 12.82 \\
\hline & Dizziness & 2 & 5.12 \\
\hline & $\begin{array}{ll}\begin{array}{l}\text { Skin rashes or } \\
\text { allergy }\end{array} & \\
\end{array}$ & 23 & 58.97 \\
\hline & Abdominal pain & 3 & 7.6 \\
\hline & Most of the above & 7 & 17.94 \\
\hline & Other & 5 & 12.82 \\
\hline \multirow{4}{*}{$\begin{array}{l}\text { Suffering from } \\
\text { long-term health } \\
\text { issues (you or } \\
\text { family members) }\end{array}$} & Cancer & 2 & 4 \\
\hline & Asthma & 7 & 14 \\
\hline & $\begin{array}{ll}\text { Chronic } & \text { skin } \\
\text { diseases } & \end{array}$ & 8 & 16 \\
\hline & bronchitis & 5 & 10 \\
\hline \multirow{3}{*}{$\begin{array}{l}\text { Experiencing other } \\
\text { adverse impact due } \\
\text { to the use of } \\
\text { agrochemicals }\end{array}$} & $\begin{array}{l}\text { Increase } \\
\text { pest/insect }\end{array}$ & 27 & 54 \\
\hline & $\begin{array}{l}\text { Environmental } \\
\text { pollution }\end{array}$ & 15 & 30 \\
\hline & Animal health & 7 & 14 \\
\hline
\end{tabular}

The study revealed that the majority of the farmers $39(78 \%)$ had ill-health symptoms after agrochemicals application. Among those 39 (78\%) farmers, the most common symptoms experienced that was reported included eye irritation $(53.84 \%)$, headache $(35.89 \%)$, cough $(17.94 \%)$ and skin rashes or allergy $(58.97 \%)$. Some of the farmers $(17.94 \%)$ reported that they experienced most of the symptoms listed in the table. Two farmers reported that they have a family member diagnosed with cancer. Similarly, some farmers $(n=7)$ reported asthma, bronchitis $(\mathrm{n}=5)$ and chronic skin disease $(n=8)$ in their family members.

More than half of the farmers (54\%) reported that pest and insect activity increased after agrochemicals application. Some farmers also reported experiencing adverse impacts on their animals (14\%) and the surrounding environment.

\section{DISCUSSION}

Training is very important for farmers to use agrichemicals, take safety 
precautions, dispose of the container, minimize risks of human and environmental health, find relevant information, and so forth. In this study, a significant number of farmers $(74 \%)$ did not receive training to use agrochemicals. When compared to a similar study conducted in Nigeria $94.7 \%$ of farmers did not receive any formal training in safe pesticide use. ${ }^{(19)}$ The similar result was reported in Turkey and in Nepal that not a single farmer in their studies received training on pesticide use. ${ }^{(20,13)}$ A study conducted in Greece revealed a positive relation between training and the farmer's knowledge of pesticide use, safety behaviour, and beliefs in pesticide hazard control. (21) Hence, training should be encouraged for all farmers in the study area.

The current study indicates that all the farmers in the study area were aware of the hazards involved in agrochemicals and safety precautions. However, the majority of them (68\%) ignored safety precautions while applying agrochemicals. Likely, farmers did not feel comfortable, and PPE was not easily available as revealed in a study in Rupandehi, Nepal. ${ }^{(22)}$ Some studies indicated a low rate of PPE use by farmers. A study conducted in Palpa, Nepal observed that only $6 \%$ of farmers took complete protective measures like wearing protective clothing, hand gloves, goggles, masks, and taking bath immediately after application. (13) The findings from Bakhsh and colleagues another study in Pakistan on cotton farm workers revealed similar results as $40 \%$ young and $68 \%$ elder cotton pickers did not comply with safety measures. ${ }^{(23)}$ In Egypt more than $97 \%$ of farmers not wearing PPE while mixing and applying pesticides. (24) Another study in Chitwan, Nepal identified that PPE was not easily available hence $14 \%$ of farmers were not applying any kind of safety measures whereas $86 \%$ of them were using at least one form of PPE. ${ }^{(11)}$

The source of information about agrochemicals use for farmers in this study was mainly from friends, elders, relatives, and other farmers (40\%) followed by agrochemicals retailers and agriculture cooperatives (22\%). In Egypt, more than a quarter of farmers believed their neighbours on pesticide use. ${ }^{(24)}$ When compared to a similar study conducted in Pakistan the key source of information was stated to be the pesticide realtors, and several farmers also relied on friends, neighbours, and colleagues. (25) A study in Egypt found "ministry officials" as a major source of information. However, the information was not about the safe application but the price, dosage, and benefits of pre-and post-harvest use of pesticides. (24) In China, pesticide realtors had a great influence on farmers' decisions in choosing pesticide. (26) The radio, television, newspapers, and pamphlets are also good sources of information for farmers in this current study.

The methods of disposing of agrochemicals containers are critical to reducing adverse impacts on human health and the environment. In Cameroon, $42.43 \%$ of Cocoa farmers washed and reused agrochemical containers of the farms, and few farmers also used it for fetching and drinking water, storage for palm oil, salt, and other food spices. ${ }^{(27)}$ The current study revealed a similar result where $36 \%$ of farmers reused those containers for storage or other household purpose and very few $(8 \%)$ farmers used safe disposal procedures i.e., burn or bury. Öztaş and colleagues indicated that $10 \%$ of farmers in Turkey washed and reused them and $31.0 \%$ of them threw them away. (20) Some farmers in Cameroon were found pouring agrochemical leftovers in their farms and nearby running rivers or streams. The current study also indicated a similar result as some farmers pour it near to their farms. This kind of practice poses a significant risk to public health and livestock and the environment. ${ }^{(19)}$

The majority of the farmers $(78 \%)$ in this current study reported ill-health symptoms after agrochemicals application such as (table 7) eye irritation, headache, cough, and skin rashes or allergy which was 
not surprising because a majority of them neglected in the application of safety precautions even though they were aware of hazard associated with agrochemicals. A similar study indicated that $91.3 \%$ of the farmers or their families reported ill-health symptoms during or after pesticide use. ${ }^{(19)}$ Some other studies also find similar findings. ${ }^{(20,19,23)}$ The elder Pakistani cotton pickers face severe and more health problems as they involved many consecutive years in cotton picking than younger ones. ${ }^{(23)}$

\section{CONCLUSION}

The results of the study indicated that a significant number of the farmers' access information on agrochemicals use from friends, elders, relatives, and other farmers followed by agrochemicals retailers and agriculture cooperatives. Urea, DAP, potash, and other pesticides were mostly used as agrochemicals in the study area. Training and awareness are critical to use agrichemicals; however, most farmers have not received any sorts of training even though all of them were aware of the hazards involved in agrochemicals. Research revealed that attitude towards receiving training is independent of gender. The majority of farmers found ignoring safety precautions and inappropriately applying agrochemicals. It was evident that females are more likely to use safety measures than males and the higher educational status of respondents plays a vital role in applying safety measures. The most common PPE used by slightly more than a quarter of farmers were rubber gloves, safety shoes, masks, hats, longsleeved clothes, goggles, and respirators. All the farmers washed their hands with soap while very few of them only took bath immediately after applying agrochemicals. The agrochemical storage and disposal of containers were also found inappropriate. More than half of the farmers stored their agrochemicals unlocked inside the house, posing risk to the children and families. A significant number of farmers reported ill- health symptoms after applying agrochemicals. The most frequent symptoms experienced by them were eye irritation, headache, cough, skin rashes or allergy, vomiting, dizziness, and abdominal pain. Some farmers also reported chronic illnesses such as asthma and bronchitis. Inadequate knowledge and inappropriate practice have resulted in harmful consequences to the farmers' health and the surrounding environment.

Based on the results of the study, training for farmers is strongly recommended to improve knowledge on agrochemical use, risk associated with agrochemical, safety precaution, safe storage and disposal and short and longterm health impact. Agrochemical retailers and agriculture cooperatives should also be trained because they are one of the primary sources of information on agrochemicals for farmers. Since a significant number of farmers in the study area also rely on the news and information on local television and radio, various awareness programs such as interviews with other experienced farmers, experts, trainers, and documentaries about the best practices of agrochemicals should be launched. Furthermore, to manage inappropriate disposal practices of the farmers, the local government should provide a common agrochemicals waste disposal site where there is no threat to public health and the environment. The demand for organic vegetables is increasing lately in Kathmandu metropolitan city. Therefore, government organizations can promote organic farming to reduce the negative consequences of agrochemicals on human health and the environment.

The observation of the study area identified that many farmers use groundwater for the household including drinking purposes. The likelihood of widespread groundwater contamination seems high as a result of inappropriate agrochemicals application and disposal practice. Hence, further research can be done to identify the severity of groundwater 
contamination. In addition, there is also need to conduct research on why farmers are negligent about wearing PPE although they are aware of hazards involved in agrochemicals.

\section{ACKNOWLEDGEMENT}

This manuscript is part of a faculty research report entitled "Assessment of farmer's attitude towards the use of chemical fertilizer and pesticides in Sankhu, Bajrayogini and Machhegaun VDCs, Kathmandu." The authors gratefully acknowledge the Research Division, Rector's Office, Tribhuvan University for providing funding for this study and all the farmers and representatives of Machhegaun and Sankhu VDCs for their enthusiastic contribution and valuable time.

Disclosure: The authors declared that there is no conflict of interest.

\section{Source of Funding: None}

\section{Ethical Approval: Approved}

\section{REFERENCES}

1. MoALD (2019) Statistical Information on Nepalese Agriculture 2017/2018. Agri Statistics Section, Monitoring, Evaluation and Statistics Division, The Ministry of Agriculture and Livestock Development, Singha Durbar, Kathmandu, Nepal.

2. Shrestha, R. (2010). Fertilizer Policy Development in Nepal. Journal of Agriculture and Environment, 11, 126-137. https://doi.org/10.3126/aej.v11i0.3660

3. MOAC, 2004. National Agricultural Policy, 2061 (Nepali). Kathmandu: Ministry of Agriculture and Cooperative.

4. Krishi Diary (2019), The Ministry of Agriculture and Livestock Development, Singha Durbar, Kathmandu, Nepal. Retrieved from krishi-diary-2076.pdf (pmamp.gov.np)

5. John, P.J., Bakore, N. and Bhantnagar, P. (2001). Assessment of organochlorine pesticides residue levels in dairy milk and buffalo milk from Jaipur city, Rajasthan, India, Enviro. Internat., 26 : 231- 236
6. Ghimire, A. and Khatiwada, B.(2001), Use of Pesticides in Commercial Vegetable Cultivation in Tandi, Eastern Chitwan, Nepal, Institute of Agriculture and Animal Science, Chitwan Nepal.

7. Palikhe, B.R. (2002), Challenges and options of pesticide use: In the context of Nepal, Landschaftsökologie und Umweltforschung 38 p. 130-141 Braunschweig 2002

8. Ecobichon D.J. (1996), Toxic Effects of Pesticides, 5th Edition New York: MacMillan, 643-689

9. Engel, L., O'Meara, E., \& Schwartz, S. (2000). Maternal occupation in agriculture and risk of limb defects in Washington State, 1980-1993. Scandinavian Journal of Work, Environment \& Health, 26(3), 193198. Retrieved March 25, 2021, from http://www.jstor.org/stable/40967048

10. Miller G.T. (2004), Sustaining the Earth, 6th edition, Thompson Learning, Inc. Pacific Grove, California. Chapter 9, Pages 211216.

11. Rijal, J., Regmi, R., Ghimire, R., Puri, K., Gyawaly, S., \& Poudel, S. (2018). Farmers' Knowledge on Pesticide Safety and Pest Management Practices: A Case Study of Vegetable Growers in Chitwan, Nepal. Agriculture, 8(1), 16. MDPI AG. Retrieved from http://dx.doi.org/10.3390/agriculture801001 6

12. Bhandari, G. (2014). An Overview of Agrochemicals and Their Effects on Environment in Nepal. Applied Ecology and Environmental Sciences, 2(2), 66-73.

13. Sharma, B., Ojha, B. R., Ojha, A., Sapkota, B., Adhikari, G., \& Gautam, S. (2021). Assessment of Pesticide Application Pattern in Major Vegetables of Palpa District, Nepal. International Journal of Social Sciences and Management, 8(1), 292-298. https://doi.org/10.3126/ijssm.v8i1.32694

14. Giri N. (2010), Pesticide Use and Food Safety in Kathmandu Valley, Nepal, Institute of Soil Research, University of Natural Resources and Life Sciences, (BOKU), Vienna, 2010

15. Shrestha B., Maskey S.L., Shrestha R.K., Tripathi B.P.,Khadga Y.J.,Munankarmy R.C., Bhattarai E.M.and Shrestha. S.P.(2000), Soil Fertility Management: Farmers Practices and Perceptions in the Hills of Nepal, Lumle 
Sharmila Ranabhat et.al. Knowledge, attitude, and practice of agrochemicals use among farmers in Kathmandu, Nepal.

Technical Paper No. 2000/4. Lumle (Nepal): LARC.

16. CBS (2011). National Population and housing report, Central Bureau of Statistics, Kathmandu, Nepal, 2012.

17. Shrestha, K., Shrestha, G., \& Pandey, P. (2014). Economic analysis of commercial organic and conventional vegetable farming in Kathmandu Valley. Journal of Agriculture and Environment, 15, 58-71. https://doi.org/10.3126/aej.v15i0.19816

18. Bhatta, G.D.; Doppler, W. Socio-economic and environmental aspects of farming practices in the peri-urban hinterlands of Nepal. J. Agric. Environ. 2010, 11, 26-39.

19. Oluwole, O., \& Cheke, R. (2011). Health and environmental impacts of pesticide use practices: a case study of farmers in Ekiti State, Nigeria. International Journal of Agricultural Sustainability, 7(3), 153-163. https://doi.org/10.3763/ijas.2009.0431

20. Öztaş, D., Kurt, B., Koç, A., Akbaba, M., \& İlter, H. (2018). Knowledge Level, Attitude, and Behaviors of Farmers in Çukurova Region regarding the Use of Pesticides. BioMed Research International, 2018, 6146509-7.

https://doi.org/10.1155/2018/6146509

21. Damalas, C., \& Koutroubas, S. (2017). Farmers' Training on Pesticide Use Is Associated with Elevated Safety Behavior. Toxics (Basel), 5(3), 19-. https://doi.org/10.3390/toxics5030019

22. Bhandari, G., Atreya, K., Yang, X., Fan, L., \& Geissen, V. (2018). Factors affecting pesticide safety behaviour: The perceptions of Nepalese farmers and retailers. The Science of the Total Environment, 631-632, 1560-1571.

https://doi.org/10.1016/j.scitotenv.2018.03.1 44

23. Bakhsh, K., Ahmad, N., Tabasum, S., Hassan, S., \& Hassan, I. (2017). Health hazards and adoption of personal protective equipment during cotton harvesting in Pakistan. The Science of the Total Environment, 598, 1058-1064. https://doi.org/10.1016/j.scitotenv.2017.04.0 43

24. Ibitayo, O. (2006). Egyptian Farmers' Attitudes and Behaviors Regarding Agricultural Pesticides: Implications for Pesticide Risk Communication. Risk Analysis, 26(4), 989-995. https://doi.org/10.1111/j.15396924.2006.00794.x

25. Damalas, C., \& Khan, M. (2016). Farmers' attitudes towards pesticide labels: implications for personal and environmental safety. International Journal of Pest Management, 62(4), 319-325. https://doi.org/10.1080/09670874.2016.119 5027

26. Wang, Y., Wang, Y., Huo, X., \& Zhu, Y. (2015). Why some restricted pesticides are still chosen by some farmers in China? Empirical evidence from a survey of vegetable and apple growers. Food Control, 51, 417-424. https://doi.org/10.1016/j.foodcont.2014.12.0 02

27. Oyekale, A. (2018). Cocoa farmers' compliance with safety precautions in spraying agrochemicals and use of personal protective equipment (PPE) in Cameroon. International Journal of Environmental Research and Public Health, 15(2), 327-. https://doi.org/10.3390/ijerph15020327

How to cite this article: Ranabhat S, Baskota S, Bajagain B. Knowledge, attitude, and practice of agrochemicals use among farmers in Kathmandu, Nepal. Int J Health Sci Res. 2021; 11(6): 89-99. DOI: https://doi.org/10.52403/ ijhsr.20210613 